\title{
Fan-tagonismo nas redes sociais: Controvérsias entre fãs da novela Sete Vidas
}

\section{Cecília Almeida Rodrigues Lima}

Mestre em Comunicação Social pelo Programa de Pós-Graduação em Comunicação da Universidade Federal de Pernambuco (PPGCOM-UFPE) e atualmente doutoranda no mesmo programa, onde estuda televisão e sua articulação com novas mídias. É docente na Faculdade Boa Viagem (FBV/DeVry). E-mail: cecilia.almeidarl@gmail.com
Resumo: Este artigo analisa os conflitos constitutivos de comunidades de fãs, em suas disputas por domínio discursivo sobre um mesmo objeto midiático. Entende os grupos de fãs não como comunidades fechadas e coerentes, mas como espaços de embates e antagonismo que se manifestam na forma de controvérsias, disputas e discussões. Traz como objeto de análise a telenovela Sete Vidas, exibida em 2015 pela Rede Globo de Televisão. O folhetim em seus capítulos finais provocou a divisão dos fãs em dois grupos de shippers (\#PeJu e \#JuLipe) que disputaram até o último momento para defender sua hipótese, se utilizando de diversos argumentos para tentar vencer a disputa. Tais grupos se utilizaram do Twitter e da própria Fan Page da Rede Globo para expressar seus argumentos, que foram categorizados e analisados enquanto topoi discursivos.

Palavras-chave: Cultura de fãs; Telenovela; Redes sociais; Controvérsia.

Fan-tagonism in social networks: controversy among fans of Globo's Sete Vidas

Abstract: This paper analyses conflicts that constitute fan communities, in their disputes for discoursive domain over a media object. It understands fandom not as coherent and closed communities, but as spaces that favor disputes and antagonism that are expressed in the form of controversies, disputes and discussions. Our object of analysis is the telenovela Sete Vidas, exhibited by Rede Globo de Televisão in 2015. The final chapters of the novela splitted fans into two groups of shippers (\#PeJu and \#JuLipe), that disputed up until the last moments to prove their hypothesis and win. Those groups have used Twitter and Rede Globo's Fan Page on Facebook to express their arguments, that were analysed and categorized as discoursives topoi.

Keywords: Fandom; Telenovela; Social networks; Controversy. 


\section{Introdução}

Os estudos sobre fãs (FISKE, 1992; JENKINS, 1992) a princípio deixaram de lado a existência de conflitos em suas relações, para valorizar o potencial criativo de ressignificação interpretativa e subversão dessas comunidades. Num primeiro momento, as comunidades de fãs foram interpretadas como unidades sólidas e homogêneas, com discurso único, onde as eventuais rupturas ocorreriam em caráter de exceção.

No entanto, observa-se que as comunidades de fãs agrupam indivíduos de procedência e formação extremamente heterogênea, de modo que as discordâncias surgem como um processo constitutivo da própria cultura de fãs, e não como "aberrações momentâneas" (JOHNSON, 2007). Estudiosos começaram a identificar processos de disputa contínua por domínio discursivo, não somente entre fãs e produtores, como também entre os próprios fãs.

As divergências dentro de uma mesma comunidade de fãs ocorrem em torno de diversos motivos: mudanças na narrativa, diferentes práticas interpretativas, carisma das celebridades, (in) coerência textual, quebra nas expectativas formadas a partir do contrato de leitura etc. Qualquer elemento narrativo que venha a potencialmente ameaçar a "segurança ontológica" (SILVERSTONE, 1994) proporcionada pelo objeto midiático pode vir a se tornar motivo de uma controvérsia.

No que diz respeito às controvérsias, um grupo específico de fãs tende a se destacar de maneira mais ativa no cerne de tais comunidades: os shippers (a alcunha vem da palavra em inglês relationship, que significa relacionamento). Esses são fãs cujo investimento emocional na narrativa depende da formação de casais românticos entre personagens específicos. Na maioria dos casos, os shippers de um determinado casal só obtêm prazer na experiência ficcional se existem elementos diegéticos que sustentem - ou ao menos insinuem - um determinado romance. Mais do que torcer por um determinado romance fictício, o deleite dos shippers depende dele.

As telenovelas da Rede Globo de Televisão têm o romance como um de seus principais temas. A grande maioria dos folhetins brasileiros apresentam casais, ou possíveis casais, e os contratempos que enfrentam para encontrarem seu final feliz. Um elemento recorrente para servir como obstáculo é a presença dos triângulos amorosos, que costumam provocar a divergência na opinião das audiências. Fãs se dividem entre defensores de um determinado par, patronos do outro e, muitas vezes, advogados de que poderia haver uma terceira opção, imaginada por eles próprios.

Em 2015, o folhetim Sete Vidas, exibido na faixa das 18h, atraiu um forte envolvimento das audiências, que se expressaram nas redes sociais digitais. Entre outras coisas, a etapa final da trama girou em torno de um triângulo amoroso vivido pelos personagens Júlia (Isabelle Drummond), Pedro (Jayme Matarazzo) e Felipe (Michel Noher).

Os eventos da telenovela logo dividiram a audiência entre shippers do casal Júlia/Felipe (JuLipe) e de Júlia/Pedro (PeJu), promovendo disputas e incentivando o ativismo dessas facções nos ambientes online, na forma de manifestações que pediam à Rede Globo que optasse pelo desfecho que achavam mais interessante. A emissora elegeu PeJu como o casal que ficaria junto no capítulo final, que foi exibido no dia 10 de julho, para decepção da maioria dos que se manifestaram na enquete promovida no site na emissora. Uma numerosa parcela de fãs utilizou as redes sociais digitais para expressar sua insatisfação. 
${ }^{1}$ Do original: La televisión nos acompaña cuando nos levantamos, tomamos el desayuno, bebemos um té o vamos a um bar. Nos reconforta cuando estamos solos. Nos ayuda a dormir. Nos brinda placer, nos aburre y a veces no cuestiona. Nos da la oportunidade de ser sociables y también solitários. [...] La televisión nos parece hoy natural como nos lo parece na vida cotidiana.
A polêmica gerada em torno de algo aparentemente tão banal foi intensa e apaixonada. Os ânimos ficaram tão acalorados que o tema se tornou um dos tópicos mais comentados na rede social digital Twitter, no dia em que o capítulo final de Sete Vidas foi exibido. Partidários de \#JuLipe utilizaram as redes para lamentar o desfecho da trama de modo indignado, interpretando como narrativamente incoerente o final escolhido pelo "cânone".

Este artigo busca analisar as conversações em torno do final da telenovela Sete Vidas nas redes sociais digitais, entendendo-as como discursos de natureza controversa e antagônica. Serão observadas as disputas entre as facções de shippers dos respectivos casais e suas estratégias para desqualificar o discurso do outro. Terá como principal corpus de análise as menções feitas no Twitter com as hashtags \#JuLipe e \#PeJu, publicadas no período da última semana de exibição da telenovela. Também observará os comentários dos fãs na Fan Page do Gshow no Facebook.

\section{Ser fã}

A narrativa seriada, talvez a forma textual mais icônica da televisão, tem o poder de nos fisgar de tal forma que somos capazes de investir uma grande quantidade de tempo e de emoção para acompanhar sua trajetória. Seriados norteamericanos de longa duração garantem a fidelidade de audiências que, de tão envolvidas, sentem pessoalmente o que ocorre com os personagens encenados. Não requer muito esforço imaginar um motivo para tal resultado. As pessoas e histórias ali representadas fazem parte da rotina dos espectadores, muitas vezes durante anos, dentro de seus lares, na sala de estar, em seus quartos, ainda um pouco antes de dormir, enfim, participam de suas vidas.

A televisão nos acompanha quando acordamos, quando tomamos café da manhã, quando tomamos chá e vamos a um bar. Nos conforta quando estamos sozinhos. Nos ajuda a dormir. Nos dá prazer, nos entedia e às vezes nos questiona. Nos dá a oportunidade de sermos sociáveis ou solitários. [...] A televisão hoje nos parece natural como nos parece natural a vida cotidiana (SILVERSTONE, 1994: 20, tradução nossa) ${ }^{1}$.

As consequências emocionais do consumo de narrativas seriadas podem ser muitas. A morte de um personagem nas telas pode nos doer como dói a morte de um conhecido; o cancelamento abrupto do programa pode nos fazer falta como nos faria um ente querido; o fracasso de um protagonista querido pode nos indignar como se fosse o fracasso de um amigo próximo. Roger Silverstone (1994), tomando emprestado conceitos formulados por autores como o sociólogo Anthony Giddens, entende a presença da televisão nas nossas vidas como uma espécie de segurança ontológica, uma zona de conforto proporcionada pela repetição de certos rituais em nosso cotidiano. Ter a presença de um grupo de personagens em nossos lares, todas as semanas, no mesmo horário, é algo que nos traz segurança.

A partir desse envolvimento mais afetuoso com determinados objetos midiáticos, nos tornamos fãs de alguma coisa. O termo, embora muitas vezes ainda esteja associado pelo senso comum a uma legião de ignóbeis obsessivos e seus rituais estranhos, foi ressignificado pela academia, especialmente a partir dos estudos de John Fiske (1992) e Henry Jenkins (1992; 2008). A atuação criativa dos fãs em torno dos produtos midiáticos e as complexas relações entre fãs e produtores motivou diversas pesquisas partindo de pontos de vistas diferentes e tentando compreender, exatamente, o que significa ser fã.

Conforme Booth (2010), consideramos fãs como espectadores envolvidos com um determinado objeto midiático, dispostos a investir uma grande quantidade 
de tempo e energia para pensar sobre e interagir com ele. Silverstone (1994) e outros autores (HILLS, 2002) compreendem a relação afetiva de espectadores com a televisão a partir do conceito de objetos transicionais, postulado do psicanalista infantil Donald Winnicott. Em linhas gerais, indica um processo de transferência do afeto materno para determinados objetos físicos, como brinquedos, para trazer segurança nos momentos em que a criança sente a falta da mãe. Para esses autores, os objetos midiáticos ocupariam um lugar semelhante nas mentes e corações dos indivíduos, mesmo na vida adulta, o que estaria diretamente relacionado ao processo de se tornar fã de um objeto midiático ficcional.

E se, lembrando novamente os dizeres de Silverstone, a televisão nos dá a oportunidade de sermos sociáveis, é compreensível que fãs de uma mesma coisa se reúnam para compartilhar experiências, opiniões e sentimentos provocados pelo objeto midiático em questão. Fãs se constituem em grupos, formando redes que se conectam com a finalidade de promover essa troca e de explorar o prazer lúdico que podem extrair dos textos que consomem.

\section{Ser fã numa sociedade em rede}

Com o advento das mídias digitais e subsequente multiplicação dos pontos de acesso à informação, o consumo de objetos midiáticos passou a ser extremamente facilitado, de modo que ser fã passou a ser um aspecto integrante do cotidiano da maior parte das pessoas. Todos somos fãs de alguma coisa (BOOTH, 2010). Essa definição não está mais restrita a grupos que se reúnem em convenções e fanzines, e as práticas não se limitam a usar as roupas de seus personagens favoritos, disseminar notícias ou produzir fan fictions. A migração das comunidades de fãs para a internet fez surgir uma infindável quantidade de sites, fóruns, listas de discussão, entre outros ambientes voltados para a adoração, em vários graus, de objetos midiáticos (GRAY; SANDVOSS; HARRINGTON, 2007).

As novas ferramentas, além de ampliarem o acesso a conteúdos narrativos, possibilitaram novas maneiras desses grupos se organizarem e se relacionarem entre si, interagindo também com as instâncias produtoras e com as próprias celebridades. Finalmente, com o uso das novas mídias, os fãs criam o que Booth (2010) chama de "filosofia do brincar", intrincada nesse consumo. Para o autor, não haveria atuação dos fãs se ela não fosse prazerosa e lúdica.

Fãs utilizam a tecnologia digital não apenas para criar, modificar, piratear ou escrever textos com base nos conteúdos originalmente divulgados pelas indústrias midiáticas, mas também para compartilhar, experimentar de maneira conjunta e de alguma forma estar vivo nessas comunidades (BOOTH, 2010). Liesbet Van Zoonen (2004) considera os fãs como indivíduos mais propensos a se organizarem como grupo, porque essa é uma parcela da audiência que mantém um grande investimento individual e emocional no texto. Em grupo, fãs costumam se envolver em discussões sobre a qualidade do texto, além de propor e discutir alternativas que também poderiam ser implementadas se o texto midiático se desenrolasse à sua vontade.

O fato de que celebridades e produtores também estão presentes nessas novas mídias é um fator preponderante para que essas discussões e produções possam ser direcionados para uma espécie de ativismo de fãs (BENNETT, 2012). A partir das interações com as instâncias produtoras e dos espaços cada vez mais abertos à participação, esses grupos mobilizados em rede esperam ser ouvidos e alcançar/persuadir um maior número de pessoas. 


\section{“Fan-tagonismo"}

No entanto, não estamos querendo afirmar que tais comunidades sejam coerentes e fechadas nelas mesmas, mas, ao contrário, são espaços que possibilitam um enorme fluxo de opiniões distintas, embates e controvérsias. As redes de fãs dificilmente se formam de modo homogêneo ou em torno de valores completamente consonantes. $\mathrm{O}$ fato de que os atores envolvidos compartilham interesses e certos gostos em comum não quer dizer que essas comunidades sejam espaços de harmonia.

Um mesmo objeto midiático pode atrair grupos extremamente heterogêneos de indivíduos, com diferentes repertórios, formações políticas, contextos sociais e práticas de leitura. Embora as primeiras pesquisas sobre fãs tentassem dar conta do fenômeno descrevendo comunidades fechadas e sólidas, com discurso único, essa ideia já foi contrariada.

Jenkins (1992) já havia percebido que a paixão de fãs muitas vezes leva a disputas entre eles, embora o autor não tenha dado devida atenção a esse tipo de conflito num primeiro momento. Desde então, ele e outros estudiosos demonstraram as tensões existentes dentro de comunidades de fãs em diferentes aspectos, conforme explica Derek Johnson (2007). Esses estudos começam a dar conta das desigualdades existentes no cerne da cultura de fãs, embora de maneira geral ainda enxerguem esse fato como processos de ruptura momentâneos que eventualmente emergem dentro de um consenso prévio existente.

Em relação a isso, Johnson (2007: 21) propõe que essas contínuas disputas por domínio discursivo são constitutivas da própria cultura de fãs, que pode então ser caracterizada como uma disputa pela hegemonia de interpretação e avaliação, através da qual as relações entre fã, texto e produtor são perpetuamente articuladas, desarticuladas e rearticuladas. Em seus discursos, fãs constroem "verdades" dissonantes sobre os mais variados aspectos daquilo que consomem, se utilizando de espaços de socialização para expressar suas verdades e fazê-las valer, num cenário de disputa por hegemonia discursiva. Esses conflitos ocorrem tanto entre facções internas de uma comunidade de fãs como entre fãs e produtores.

Nesse sentido, toda reviravolta ou mesmo uma mudança sutil na narrativa pode se tornar motivo de controvérsias. A morte de um personagem importante, o rompimento de um casal, a introdução de um novo antagonista, a quebra no contrato de leitura, enfim, tudo o que pode interferir na tal segurança ontológica proporcionada pelo objeto midiático é passível de se transformar num tema que divide opiniões e discursos. Além disso, a própria coerência da trama está constantemente sendo colocada à prova pelo olhar exigente desses consumidores, capazes de identificar eventuais furos e inconsistências narrativas que rapidamente também se convertem em motivo de oposições discursivas no interior das comunidades. As disputas discursivas entre fãs que defendem pontos de vistas antagônicos sobre os mais variados aspectos de um mesmo objeto midiático - fan-tagonismo, na tradução livre do termo utilizado por Johnson (2007) - são disputas de poder em torno do domínio interpretativo de um dado texto, que se materializam na forma de interações antagônicas.

\section{Interações antagônicas: polêmica, controvérsia, disputa e discussão}

As relações antagônicas entre fãs de um mesmo objeto midiático estabelecem interações de oposição, onde os participantes se utilizam de argumentos lógicos e emocionais para tentar obter maior poder - ou seja, adesão - dentro de uma 
comunidade discursiva. Para tratar do assunto com propriedade, uma digressão teórica é necessária para distinguir os conceitos de controvérsia, disputa, discussão e, finalmente, de polêmica.

Segundo Rodrigues (1998), para Dascal, existem três tipos ideais de oposição discursiva. São eles as disputas, controvérsias e discussões. $O$ autor esclarece que esses três tipos de oposição se distinguem uns dos outros pelos seus objetivos respectivamente: vencer, convencer ou resolver um problema. O objetivo em função do qual se constroem as intervenções textuais possuem papel fundamental, tanto para estabelecer a forma como o discurso será estruturado, quanto para determinar a capacidade de resolução da oposição, com o reestabelecimento de equilíbrio. Ele nota que, na controvérsia, não se consegue apurar, ao final da interação, vencedores ou vencidos - o que significaria que algum dos participantes mudasse sua maneira de pensar. Normalmente, portanto, a controvérsia tende a ser longa e inconclusiva (RODRIGUES, 1998).

Dascal (in RODRIGUES, 1998) compreende ainda que os discursos polêmicos são compostos por uma mistura entre esses três tipos ideais de oposição, considerando a presença de um componente de caráter lógico e outro de caráter afetivo. Sendo assim, as propriedades discursivas dos três tipos ideais podem aparecer de maneira combinada, não necessariamente excludente, dando início à polêmica. Por conta disso, há a possibilidade de aparecerem traços como a desqualificação do adversário, o envolvimento emocional do locutor e a virulência das avaliações, características da polêmica, em interações qualificadas predominantemente como controvérsia.

As relações antagônicas travadas entre fãs, no objeto em questão, apresentam características pertinentes aos três tipos ideais de oposição pontuados por Dascal. Verificou-se que ora os discursos buscavam vencer, ora convencer, ora solucionar o problema e que, em alguns momentos, os três objetivos apareciam simultaneamente. $\mathrm{O}$ discurso virulento, apaixonado, com forte envolvimento emocional e com argumentos que visavam a desqualificação dos adversários se mostrou típico nas interações entre fãs com posições antagônicas, como veremos a seguir.

\section{Sete Vidas}

As telenovelas da Rede Globo, apesar de terem uma vida útil muito menor do que os seriados norte-americanos bem-sucedidos, também são capazes de fomentar a criação de comunidades de fãs e de suas disputas. $O$ folhetim "Sete Vidas", exibido na faixa das $18 \mathrm{~h}$, atraiu um forte envolvimento das audiências, que se expressaram nas redes sociais digitais. Entre outras coisas, a etapa final da trama girou em torno de um triângulo amoroso vivido pelos personagens Júlia (Isabelle Drummond), Pedro (Jayme Matarazzo) e Felipe (Michel Noher).

Sete Vidas apresentou os protagonistas Júlia e Pedro, que se sentem atraídos um pelo outro à primeira vista, mas logo depois são convencidos de que são irmãos biológicos. Após a desilusão amorosa, ambos encontram novos pretendentes e iniciam novos relacionamentos. Mais adiante, descobrem que não são irmãos e têm uma impulsiva noite de amor, traindo seus respectivos pares.

Apaixonados, decidem se separar de seus namorados e começar uma vida juntos. Júlia cumpre com o combinado, mas Pedro recebe a notícia de que a namorada (Maria Flor) está grávida de um filho dele e não tem coragem de confessar a infidelidade e encerrar o relacionamento. A decisão é motivo de grande sofrimento para Júlia, que apenas se recompõe quando conhece Felipe, 
2 Disponível em:

http://gshow.globo.com/participe/votac aomultimidia/2015/07/com-quem-voceacha-que-julia-deve-ficar-no-final-desete-vidas.html>.

Acesso em: 08 dez 2015.
${ }^{3}$ Disponível em:

https://www.facebook.com/portalgshow /posts/531367057020824

Acesso em: 08 dez 2015. meio-irmão de Pedro. Ao saber da união, Pedro volta atrás e tenta reconquistar Júlia.

O desfecho mais previsível para a telenovela seria de que, após os obstáculos enfrentados, o casal Pedro/Júlia (PeJu) se reunisse novamente. No entanto, a faç̧ão de fãs shippers do par Júlia/Felipe (JuLipe) se manifestou de maneira extremamente expressiva nos ambientes online. "Júlia e Felipe construíram uma relação de amor que merece um final feliz", comenta uma shipper do casal.

A Rede Globo chegou a realizar uma consulta popular por meio de enquete no site de entretenimento Gshow, onde o par JuLipe obteve maioria dos votos (mais de $70 \%)^{2}$. O resultado foi celebrado pelos usuários, que se sentiram vitoriosos: "Olha o Felipe ganhando de lavada no site de \#SeteVidas no @gshow! Chuuuuupa, Pedro!", foi o comentário de um internauta no Twitter. Outra publicação na rede mostrava esperanças: "Acho que a enquete do GShow pode ser um indício de \#Julipe no final". Nesta mídia, entre os dias 03 e 10 de julho, última semana de exibição da novela, 1.239 publicações com a hashtag \#JuLipe foram publicadas, enquanto 589 utilizaram a hashtag \#PeJu no mesmo período.

Enfim, no último capítulo, a Rede Globo elegeu o casal Pedro/Júlia, contrariando grande parte dos fãs. Embora a novela tenha sido extremamente elogiada, de modo geral, o fandom se mostrou insatisfeito e protestou. "A novela é para o público e o público quer \#Julipe", como colocou uma shipper no Twitter, se utilizando da maior popularidade do casal como argumento. Esse tipo de menção, que se sustenta com base numa suposta hegemonia de opinião para se fortalecer, foi extremamente recorrente.

A autora Lícia Manzo foi alvo dos comentários de diversos espectadores, sendo diretamente acusada de "estragar" a novela. "Por mais bonito que seja esse último capítulo de \#SeteVidas, a autora não me convencerá que Júlia e Felipe não deveriam ficar juntos". O tom de decepção foi generalizado: "Fui otária!", comentou uma espectadora. $\mathrm{O}$ argumento do desejo da maioria foi utilizado diversas vezes. Outros fãs imaginaram seu próprio final: "No meu pensamento \#Julipe viveram felizes para sempre e pedro morreu atropelado!". Também houve quem propusesse um boicote a "Além do Tempo", folhetim que substituiu "Sete Vidas", em retaliação.

Enquanto isso, a facção PeJu comemorava: "aceitem que o amor supera o tempo e os erros, aceitem \#Peju", foi o argumento de um espectador. Entre esses shippers, a grande maioria dos argumentos utilizados foram justificados pela própria diegese, se valendo do sentimento inabalável que existiria entre os dois personagens. Nas palavras de um usuário, "Júlia e Pedro se amam. E contra fato não há argumento".

Cada um dos lados apresentou argumentos esperando que a emissora se apresentasse como uma instância mediadora, que daria fim ao conflito escolhendo o desfecho mais justo para os personagens.

Para este estudo, foram analisadas, no Twitter, 1.239 publicações com a hashtag \#JuLipe e 589 com hashtag \#PeJu, publicadas na última semana de exibição da telenovela. Os posts foram coletados com o uso da ferramenta gratuita NodeXL, que captura comentários feitos publicamente na mídia social. Já na página do Gshow, no Facebook, foram analisados os 1.215 comentários feitos na publicação de 10 de julho, relativa ao desfecho da telenovela ${ }^{3}$.

A partir dos comentários, os topoi (temáticas argumentativas) dos enunciados mais recorrentes de cada facção foram elencados e classificados. Alguns 
comentários mais emblemáticos foram selecionados como exemplos, mas os nomes de seus autores foram preservados.

\section{A controvérsia em \#JuLipe e \#PeJu}

"O choro é livre pras \#Julipe", comentou vitoriosa uma shipper PeJu que trazia de modo explícito o embate existente entre as duas facções de fãs de "Sete Vidas". Ao longo da trama, a controvérsia entre os discursos foi notada nos ambientes online, com a existência de confrontos diretos. A Rede Globo percebeu e nutriu a controvérsia, convocando os fãs a se posicionarem contra ou a favor determinado casal em diversos momentos, utilizando, além do site Gshow, seus perfis oficiais no Twitter e Facebook.

Os dois grupos com visões antagônicas se colocaram em embate constante, apresentando razões para defenderem o casal de sua preferência, numa tentativa de solucionar o conflito pelo convencimento - como vimos, característica típica da controvérsia. Abaixo, os topoi discursivos mais recorrentes entre os shippers JuLipe:

\begin{tabular}{|c|c|c|}
\hline $\begin{array}{l}\text { Topos Discursivo } \\
\text { \#JuLipe }\end{array}$ & Explicação & Exemplos de depoimentos \\
\hline $\begin{array}{l}\text { Pedro não merece } \\
\text { uma segunda } \\
\text { chance }\end{array}$ & $\begin{array}{l}\text { A rejeição ao personagem } \\
\text { Pedro foi o principal motivo } \\
\text { para a torcida desses fãs, que } \\
\text { acreditam que os erros do } \\
\text { personagem não poderiam } \\
\text { ter sido perdoados por Júlia. }\end{array}$ & $\begin{array}{l}\text { "O Pedro tinha que ficar sozinho. O } \\
\text { cara fez a garota de idiota várias } \\
\text { vezes!" } \\
\text { "O mala do Pedro fez a Júlia de } \\
\text { palhaça várias vezes e no final ele sai } \\
\text { como o bonzinho da história" } \\
\text { "Eu acredito no amor, mas com as } \\
\text { decepções que ela teve com ele, isso } \\
\text { não é amor cara, isso é burrice" } \\
\text { "Sem sal e sem graça esse final, tanto } \\
\text { para julia e Pedro e Miguel com Ligia. } \\
\text { A ingratidão tira a feição. O amor só } \\
\text { dura se for todos os dias alimentados } \\
\text { e regados com carinho, cumplicidade, } \\
\text { respeito, admiração e compressão e } \\
\text { no caso desses casais não existiam } \\
\text { nada disso Pedro e Miguel homens } \\
\text { com síndrome de piter pan" }\end{array}$ \\
\hline $\begin{array}{l}\text { Felipe é um } \\
\text { pretendente digno } \\
\text { de Júlia }\end{array}$ & $\begin{array}{l}\text { Felipe é entendido pelos fãs } \\
\text { como um pretendente "à } \\
\text { altura" de Júlia, pois a ama, é } \\
\text { carinhoso e não cometeu } \\
\text { erros com ela. A química do } \\
\text { casal de personagens } \\
\text { também foi considerada } \\
\text { como forte. }\end{array}$ & $\begin{array}{l}\text { "Felipe é homem, já este Pedro um } \\
\text { moleque" } \\
\text { "Péssimo isso, Felipe tão apaixonado } \\
\text { e saiu da novela sozinho!" } \\
\text { "a Júlia está dividida entre um } \\
\text { príncipe (Felipe) e um sapo (Pedro)" }\end{array}$ \\
\hline $\begin{array}{l}\text { O clichê não tem } \\
\text { mais graça }\end{array}$ & $\begin{array}{l}\text { O fato de que Pedro e Júlia } \\
\text { seriam um final "previsível", } \\
\text { próprio da fórmula da } \\
\text { telenovela, foi visto } \\
\text { negativamente por esses fãs, } \\
\text { que argumentam que este é } \\
\text { um desfecho pouco criativo. }\end{array}$ & $\begin{array}{l}\text { "Quer final mais clichê que Júlia e } \\
\text { Pedro só faltam se casar pra } \\
\text { completar de vez affs queremos } \\
\text { \#Julipe" } \\
\text { "Palhaçada isso de Pedro fica com } \\
\text { julha + é como eu digo hj em dia as } \\
\text { novelas n tem + criatividade n é td a } \\
\text { mesma coisa aff o mocinho termina } \\
\text { com a mocinha q chatisse nunca tem } \\
\text { nd de inovador no final é sempre a } \\
\text { merma coisa" }\end{array}$ \\
\hline
\end{tabular}




\begin{tabular}{|c|c|c|}
\hline $\begin{array}{l}\text { O público quer } \\
\text { Felipe e a } \\
\text { telenovela é feita } \\
\text { para o público }\end{array}$ & $\begin{array}{l}\text { A grande popularidade do } \\
\text { casal, medida pela própria } \\
\text { Rede Globo na enquete } \\
\text { realizada pelo site Gshow, foi } \\
\text { um dos argumentos mais } \\
\text { fortes para os shippers } \\
\text { JuLipe. }\end{array}$ & $\begin{array}{l}\text { "Mas...Que kralho de final foi esse de } \\
\text { \#SeteVidas? \#Julipe ganhou a } \\
\text { enquete, e vocês me colocam esse } \\
\text { final?@ } \odot \text { " } \\
\text { "Ela não percebeu que a grande } \\
\text { maioria do Brasil torcia pra Júlia e } \\
\text { Felipe. Ela colocou o final que ela quis } \\
\text { não o que o país gostaria" } \\
\text { "99,8\% das pessoas que assistiam } \\
\text { Sete Vidas queriam Julipe, desculpa aí } \\
\text { Projac" } \\
\text { "infelizmente, a voz do povo hoje em } \\
\text { dia não vale mais nada!" }\end{array}$ \\
\hline
\end{tabular}

Tabela 1: Topoi discursivos JuLipe

A rejeição ao personagem Pedro - que tem diretamente a ver com a falta de carisma do ator Jayme Matarazzo - foi o principal motivo para que os shippers JuLipe abraçassem sua escolha, chegando ao primeiro topos discursivo identificado pela análise. De maneira geral, muitos eram os fãs que acreditavam que Pedro deveria pagar por suas escolhas e por ter feito Júlia sofrer. Esses discursos muitas vezes pediam para Júlia escolher Felipe não especificamente por Felipe, mas para não ficar com Pedro. Pedro foi considerado por esses espectadores como "chato", um "mala", "sem sal", e sua atitude na virada da telenovela foi tida como "covarde". Uma grande quantidade de comentários afirmava que o rapaz havia perdido sua chance. Isso demonstra que a audiência se identificou fortemente com a personagem de Isabelle Drummond, que é uma atriz extremamente carismática e que costuma mobilizar um grande número de fãs, de modo que aguardavam um final que consideravam mais justo para a mocinha, numa espécie de revanchismo contra o personagem que a fez mal.

Felipe surge então como uma opção realmente à altura de Júlia, um "príncipe" em oposição ao "sapo", como uma shipper colocou no Twitter. O personagem, que se mostrou dedicado, decidido e mais maduro do que Pedro dentro de um relacionamento amoroso, caiu nas graças da audiência. $O$ fato de que ele estava apaixonado por Júlia, sem ter falhado com a personagem em momento algum, foi motivo para que o público acreditasse que ele deveria ser recompensado. A química de Júlia com Felipe foi também considerada melhor do que com Pedro.

O terceiro topos discursivo tem a ver com a repetição da fórmula da telenovela, que normalmente reúne os dois protagonistas no final. $O$ argumento de que esse enredo é pouco original e sem criatividade foi bastante utilizado pelos shippers JuLipe, que pediram um desfecho surpreendente e inovador.

O quarto argumento foge à narrativa em si e se refere justamente à maior popularidade do casal JuLipe. A enquete promovida pela Rede Globo demonstrou que o casal JuLipe tinha a preferência da maior parte do público, o que se tornou um dos argumentos mais utilizados pelos shippers deste par.

É interessante destacar que os dois primeiros topoi verificados no corpus de análise são de natureza diegética. Se tratam, portanto, de argumentos que provêm da interpretação desses fãs sobre a narrativa propriamente dita e têm a ver com o que eles consideram que seria o desfecho mais coerente do ponto de vista textual. Os demais argumentos têm outra pertinência, são "extranarrativos", por assim dizer. O topos discursivo que apela para a popularidade do casal, por exemplo, não tem a ver com a coerência do enredo em si, mas com um fator externo ao próprio texto da telenovela. A crítica feita à repetição da fórmula, do mesmo modo, se refere à expectativa desses fãs em relação ao 
contrato de leitura proposto pela telenovela. Esperavam, enfim, um desfecho mais inovador do que o praticado pelo gênero e que já se tornou fórmula.

Ainda houve um quinto argumento - que não está na tabela por ser de ataque, não de defesa - de fãs que colocaram que Pedro foi escolhido porque o ator Jayme Matarazzo é filho do diretor Jayme Monjardim Matarazzo, numa acusação de que o desfecho da novela foi decidido por nepotismo. A estratégia foi utilizada para deslegitimar o final que efetivamente foi às telas e muitos se convenceram de que a hipótese era verdadeira.

A tabela abaixo apresenta os topoi discursivos utilizados pela facção vitoriosa, PeJu, para defender sua preferência. É possível destacar também quatro principais linhas argumentativas desses fãs, sendo que cada um deles têm relação direta com os argumentos apresentados pelos shippers JuLipe.

A análise observou que os principais topoi discursivos utilizados para defender o casal PeJu foram os seguintes:

\begin{tabular}{|c|c|c|}
\hline $\begin{array}{l}\text { Topos Discursivo } \\
\text { \#PeJu }\end{array}$ & Explicação & Exemplos de depoimentos \\
\hline $\begin{array}{l}\text { Pedro merece uma } \\
\text { segunda chance de } \\
\text { se redimir }\end{array}$ & $\begin{array}{l}\text { Shippers argumentaram } \\
\text { que, apesar dos erros, } \\
\text { Pedro cresceu ao longo da } \\
\text { telenovela e sua relação } \\
\text { interrompida com Júlia } \\
\text { merece uma segunda } \\
\text { chance. }\end{array}$ & $\begin{array}{l}\text { "o Pedro é igual ao Miguel. Ambos } \\
\text { evoluíram e merecem de fato uma } \\
\text { segunda chance" } \\
\text { "Gente o Felipe seguia os sonhos dele } \\
\text { e Pedro se reencontrou e abandonou } \\
\text { tudo pela Júlia!" }\end{array}$ \\
\hline $\begin{array}{l}\text { Ninguém manda } \\
\text { no coração }\end{array}$ & $\begin{array}{l}\text { O amor de Júlia por Pedro } \\
\text { é "amor de verdade", em } \\
\text { evidência desde o } \\
\text { primeiro capítulo da } \\
\text { novela, enquanto o que } \\
\text { ela sentiu por Felipe foi } \\
\text { uma "paixonite" ou uma } \\
\text { amizade mais forte, } \\
\text { segundo a interpretação } \\
\text { desses fãs. }\end{array}$ & $\begin{array}{l}\text { "Gente as pessoas não entenderam } \\
\text { nada. Eles se amavam des do começo } \\
\text { foi um amor à primeira vista, amor de } \\
\text { verdade, mesmo o Pedro passando } \\
\text { por tudo que passou e ter feito tudo } \\
\text { errado no depois, o amor prevaleceu e } \\
\text { mostrou que prevalece sempre. Eles } \\
\text { tem uma amor que supera tudo assim } \\
\text { como do Miguel. Amei o final e chorei } \\
\text { muito" } \\
\text { "Eles se amam. Vc não pode ficar com } \\
\text { alguém apaixonado por vc se não é } \\
\text { recíproco" } \\
\text { "Eu particularmente gostei, a Julia } \\
\text { gostava do Felipe mas ela ama o } \\
\text { Pedro... Felipe era aquele amigo q a } \\
\text { gente fica em um momento ruim... } \\
\text { Novela muito linda" }\end{array}$ \\
\hline $\begin{array}{l}\text { Protagonistas } \\
\text { ficam juntos }\end{array}$ & $\begin{array}{l}\text { Argumento que se baseia } \\
\text { na própria fórmula da } \\
\text { telenovela. Já que Pedro e } \\
\text { Júlia são os protagonistas } \\
\text { que efetivamente viveram } \\
\text { uma jornada ao longo da } \\
\text { narrativa, enquanto Felipe } \\
\text { entrou na metade da } \\
\text { novela, nada mais justo do } \\
\text { que ficarem juntos. }\end{array}$ & $\begin{array}{l}\text { "Esclarecimento: o Pedro era o } \\
\text { protagonista da novela, junto com } \\
\text { Isabelle Drummond, Debora Bloch e } \\
\text { Domingos Montagner. Protagonistas, } \\
\text { geralmente, ficam juntos" } \\
\text { "Gente, a Júlia e o Pedro são } \\
\text { protagonistas. Eles foram os que mais } \\
\text { apareceram no primeiro capítulo. E } \\
\text { óbvio que iam ficar juntos" }\end{array}$ \\
\hline
\end{tabular}




\begin{tabular}{|l|l|l|}
\hline $\begin{array}{l}\text { A telenovela é da } \\
\text { autora }\end{array}$ & $\begin{array}{l}\text { Apesar de a maioria do } \\
\text { público pedir JuLipe, no } \\
\text { final o roteiro é escrito por } \\
\text { uma autora e deve seguir } \\
\text { a sua premissa inicial. }\end{array}$ & $\begin{array}{l}\text { "O mal do povo é querer controlar a } \\
\text { novela!" }\end{array}$ \\
& $\begin{array}{l}\text { "Amei o final. O autor foi fiel à } \\
\text { "não fico revoltada porque Lícia não } \\
\text { atende o desejo da maioria. Ela } \\
\text { escreve novela como quem escreve } \\
\text { um livro. É fechadinho" }\end{array}$ \\
\hline
\end{tabular}

Tabela 2: Topoi Discursivos \#PeJu

Em contraponto, os shippers PeJu defendem que o personagem Pedro merecia, sim, uma segunda chance e o perdão de Júlia, pois suas ações ao longo da telenovela mostraram que ele evoluiu e estava disposto a largar tudo pela moça. Esse foi o primeiro topos discursivo identificado, que tem diálogo direto com o primeiro topos apresentado pela facção JuLipe.

Em resposta ao segundo topos discursivo apresentado pelos fãs JuLipe, os fãs PeJu argumentam que "ninguém manda no coração". Os espectadores afirmaram, muitas vezes formulando hipóteses da vida real, que não importa se Felipe era apaixonado por Júlia, o amor entre os dois não era recíproco ("Duvido que vcs ficariam com quem não ama o suficiente...").

O terceiro topos discursivo da facção PeJu utiliza justamente a fórmula da telenovela como argumento que legitima a escolha da autora. Se Júlia e Pedro eram os protagonistas, se o enredo se desenrolou a partir deles, é natural que eles fiquem juntos ao final. Fãs afirmaram que era "óbvio" que isso aconteceria, que já era perceptível desde o primeiro capítulo e que os fãs da facção rival não teriam o direito de se revoltar por conta disso.

Finalmente, em relação ao argumento da popularidade utilizado pelos fãs de Julipe, os shippers PeJu pontuam que o público não escreve a novela, e sim a autora Lícia Manzo, que tem palavra final sobre o que é efetivamente realizado. Nota-se que mesmo alguns fãs JuLipe se deixaram persuadir por esse argumento, afirmando que a autora escreve a novela como se escreve um livro e não tem a obrigação de seguir a vontade do público.

Mais uma vez, verificou-se que os shippers se utilizaram de dois fortes argumentos que pressupõem conhecimento e envolvimento narrativo, e têm a ver com a interpretação do texto propriamente dito. As outras temáticas argumentativas foram de ordem extra-narrativa e não tratavam do enredo ou de sua coerência, mas buscavam legitimação em fatores externos a ela.

Isso demonstra que as disputas discursivas entre fãs ocorrem principalmente no âmbito da interpretação da narrativa, com cada faç̧ão querendo que sua interpretação do texto tenha hegemonia sobre outras. No entanto, esse não é o único aspecto presente na disputa: as próprias tensões entre fãs e produtores foram colocadas em jogo quando se trata da telenovela, um gênero discursivo tido por muitos autores como uma obra "aberta", isto é, uma obra que se faz quase ao mesmo tempo em que se é exibida. $O$ entendimento do público sobre esse aspecto particular da telenovela fez com que a vontade da audiência se transformasse em um argumento plausível. Os argumentos que versam sobre a própria fórmula do gênero telenovela foram postos por um público qualificado, que compreende as características próprias do texto que estão consumindo e a questionam, o que é típico da definição de fã.

Foi perceptível que os argumentos de cada faç̧ão não eram levados em consideração pelo seu rival. Nos momentos em que um lado citava o outro, era 
comum ler depoimentos como "vocês não entenderam nada" ou "vocês não têm argumento". O consenso entre as facções rivais, portanto, não foi atingido. A controvérsia foi encerrada apenas porque um novo folhetim passou a ser exibido no lugar daquele que gerou a controvérsia. $O$ embate não se resolveu, mas, como houve a substituição da "pauta" por outra, ele saiu de evidência.

\section{Considerações finais}

O conflito apresentado neste trabalho demonstra as desigualdades presentes nas relações entre fãs, bem como as disputas discursivas que esses grupos vivenciam, num constante embate por domínio interpretativo. $\mathrm{O}$ aparecimento de posições antagônicas dentro de um mesmo grupo de fãs faz surgir a controvérsia, que dificilmente é resolvida e pode ser ainda mais reforçada pela instância produtora - neste caso, a Rede Globo.

Verificou-se que a Globo alimentou a disputa entre os dois grupos, incrementando a expectativa para o desfecho da telenovela e consequentemente provocando a indignação da facção que não foi contemplada pelo final efetivamente exibido.

Nota-se que os usuários que se engajaram nessas disputas de fato apresentam um conhecimento narrativo aprofundado, bem como um forte envolvimento emocional com o texto, o que é característico da própria cultura de fãs. A identificação dos fãs com a protagonista representada pela atriz Isabelle Drummond foi especialmente marcante e que a audiência se relacionou com o sofrimento da personagem, buscando o final que seria mais justo na sua interpretação. Percebe-se que os principais topoi discursivos utilizados pelos shippers se referem a um tipo de "justiça divina" narrativa. Um final contrário ao desejado quebraria a expectativa proporcionada pelo objeto midiático. Determinados personagens, na opinião desses fãs, mereceriam recompensa ou castigo pelo seu comportamento, valorizando o lugar da telenovela como instância transmissora de boas condutas sociais.

Os outros argumentos, ditos extra-narrativos, revelam o conhecimento da audiência sobre o próprio modo de fazer da telenovela, se referindo a características do próprio gênero narrativo. Ou seja, os fãs não apenas são usuários com maior envolvimento emocional, como também são uma audiência mais qualificada e exigente.

A polêmica entre os fãs, e entre fãs e produtores, se acentuou devido à enquete realizada pela Rede Globo, que constatou a maior popularidade do casal JuLipe, mas optou por não atender a vontade da maioria. O uso desse mecanismo de consulta popular foi o grande motivo para a subsequente revolta gerada nos fãs da facção perdedora, que tiveram a falsa sensação de que tinham poder de decisão sobre o texto da novela em si.

O episódio demonstra as tensas relações de poder entre público e instância produtora, que lutam por domínio discursivo, bem como o efeito potencialmente polêmico provocado pelos novos mecanismos de participação disponíveis aos fãs e muitas vezes facilitados pelas próprias corporações midiáticas. O debate sobre autoria no ambiente de convergência midiática também aparece de maneira explícita, colocado pelas próprias audiências participativas. 


\section{Referências}

BENNETT, L. Fan activism for social mobilization: a critical review of the literature. Transformative Works and Cultures, n. 10, 2012. Disponível em: < http://journal.transformativeworks.org/index.php/twc/article/view/346/277>. Acesso em: 28 jul. 2015.

HILLS, M. Fan Cultures. Nova York: Routledge, 2002.

JENKINS, H Textual poachers: television fans and participatory culture, Nova York: Routledge, 1992.

JOHNSON, D. Fan-Tagonism. Factions, Institutions and Constitutive Hegemonies of Fandom. In: GRAY, J.; SANVDOSS, C.; HARRINGTON, C. L. Fandom: Identities and communities in a mediated world. Nova York: New York University Press, 2007.

RODRIGUES, S. M. C. V. Polémica em torno de Rumor Branco de Almeida Faria: discurso e contra-discurso. Dissertação (mestrado). Universidade do Porto, 1998.

SILVERSTONE, R. Televisión y vida cotidiana. Buenos Aires: Amorrotu, 1994.

VAN ZOONEN, L. Imagining the Fan Democracy. European Journal of Communication, n 19, p. 39-52. 2004. 